\title{
СУТНІСТЬ ТА СПЕЦИФІЧНІ ОСОБЛИВОСТІ ЗАСТОСУВАННЯ МАРКЕТИНГУ В СТРАХОВІЙ ДІЯЛЬНОСТІ
}

\begin{abstract}
У статті розглянуто сутність страхового маркетингу та його значення в забезпеченні стабільного функціонування страхової компанії. Зазначено характерні причини відмови впровадження відділу маркетингу страховиками. Визначено основні ознаки, які відрізняють страховий маркетинг від традиційного. Виділено основні сфери використання маркетингу в страховій діяльності. Охарактеризовано роль досягнень страхового маркетингу в розробиі плану стратегічних напрямків розвитку страхової компанї в перспективі. Виокремлено страховий маркетинг як пряму причину зростання прибутковості та ринкової вартості страхової компанії.
\end{abstract}

Ключові слова: страховий маркетинг, страховий продукт, страхові відносини, страховик, страхувальник, страхова компанія.

Постановка проблеми. В умовах все більшого поглиблення співпраці України з СС та появи значної кількості конкурентів на вітчизняному ринку, страхові компанії України суттєво програють в боротьбі за клієнтів іноземним страховикам. Розробка стратегії боротьби за місце на ринку потребує кардинально нових підходів та методів протидії. Хоча на сьогоднішній день до страхових компаній приходить розуміння потреби перебудови стандартної для України філософії ведення страхового бізнесу, проте повноцінне використання всіх переваг та можливостей страхового маркетингу ще й досі не досягнуто більшістю із них.

Аналіз останніх досліджень і публікацій. Визначенню сутності страхового маркетингу та основних напрямків його використання було присвячено багато праць як закордонних, так i вітчизняних вчених. Зокрема, вивченням ролі маркетингу в страховій справі та визначення його сучасних особливостей займалися такі вчені як Т.А. Говорушко [2], О.Д. Заруба [3], Е.А.Уткіна [6] й iнші. Визначенням основних сфер використання маркетингу та його елементів в страхових компаніях присвятили увагу такі науковці як В.А. Алексуніна [1], О.М. Зубец [5] та багато інших. Проте питання виокремлення причин повільного впровадження страхового

(c) Пойда-Носик Ніна Никифорівна, к.е.н., проф., професор кафедри фінансів i банківської справи економічного факультету ДВНЗ «Ужгородський національний університет», м.Ужгород

Свадеба Віктор Вікторович, аспірант 2-го курсу економічного факультету, спец. «Економіка», ДВНЗ «Ужгородський національний університет», м. Ужгород, тел.:+380956322074, E-mail: deadpoolamateras@gmail.com. маркетингу i його зв'язку із формуванням основних напрямків стратегії розвитку страхової компанії залишається невирішеним відповідно до нових викликів сучасності, а саме тих умов, у яких опинилися суб'єкти страхового ринку України під впливом факторів конкуренції та нових вимог до страхового бізнесу.

Формулювання цілей статті. У процесі даного дослідження основними цілями є: аналіз підходів науковців до трактування сутності страхового маркетингу та його ролі в забезпеченні стабільного функціонування страхової компанії; виділення характерних причин, що впливають на відмову страховиків впроваджувати маркетинг у страховий бізнес; визначення специфічних ознак та сфер використання маркетингу в страховій діяльності.

Опис основного матеріалу дослідження. Страхова діяльність в Україні характеризуються постійним зростанням кількості учасників страхового ринку, збільшенням асортименту страхових продуктів, впровадженням в страхову діяльність новітніх інформаційних технологій та динамічним зростанням конкуренції.

Попри значне зростання розмірів страхового ринку України, попит на цей вид послуг залишається низьким. Причинами цьому можуть слугувати обмежені фінансові можливості населення (через низькі доходи $\mathrm{i}$ кризову ситуацію в країні) та практично відсутня страхова культура. Останне, в свою чергу, пов'язане також із відсутністю довіри населення до страхових інститутів.

Виникає потреба у використанні нових, ефективніших методів впливу на страхові відносини між страховиком та страхувальником, які сприяли б зміцненню власних позицій в конкурентному середовищі страхового ринку. 
Ключем до вирішення даної потреби може слугувати впровадження страхового маркетингу, як невід'ємної складової страхових відносин. Адже він $є$ могутнім засобом в конкурентній боротьбі за потенційного клієнта компанії.

Питанню визначення сутності страхового маркетингу приділено увагу багатьох провідних вітчизняних та зарубіжних вчених. Зокрема, В.А. Алексуніна трактує страховий маркетинг як міст, що з'єднує інтереси страховика та страхувальника в якісних, кількісних, часових та просторових відношеннях [1, с.381]. На думку Т.А. Говорушко, маркетинг в страховій діяльності - це комплексна система дій страховика, яка спрямована на надання таких страхових послуг i в такій кількості, що відповідають потенційному попиту [2, с. 14]. О.Д. Заруба, вбачає в страховому маркетингу науку про ефективну взаємодію страховика та страхувальника, яка є комплексною методологією досліджень, на підставі результатів яких будується практична діяльність страхової компанії [3, с. 303]. Згідно погляду Е.А.Уткіна, страховий маркетинг можна розуміти як систему взаємодії страховика та страхувальника, спрямовану на взаємне врахування їх потреб та інтересів [6, с.66].

Проте, на нашу думку, найбільш детально розкриває сутність страхового маркетингу О.М. Зубец, підхід якого описує це поняття, як систему прийомів, за допомогою яких досягається взаєморозуміння й ефективна взаємодія страховика й страхувальника, тобто оптимізація їх фінансово-економічних відносин, що спрямовані на найкраще забезпечення різноманітних потреб страхувальників у якісному й повному страховому захисті в поєднанні 3 досягненням достатньої прибутковості страхових операцій для страховика. [5, с.6].

Попри те, що страховий маркетинг характеризується очевидними перевагами у веденні страхового бізнесу, значна кількість учасників вітчизняного страхового ринку досі відмовляються від його повноцінного використання у своїй діяльності. Існує ряд факторів протидії, які слугують причинами для відмови страхових компаній від відділу маркетингу. Серед них слід виділити:

1. Відсутність необхідних навичок та досвіду використання маркетингу на страховому ринку України. Практичні рекомендації зі страхового маркетингу закордоном потребують модифікацій та адаптації до вітчизняних умов функціонування.
2. Впровадження повноцінного відділу маркетингу сповільнює небажання страховиків змінювати звичні норми функціонування, в тому числі проводити перепідготовку персоналу та здійснювати перебудову наявних засад ведення бізнесу. Причиною цьому слугує страх втратити наявні короткострокові переваги та відсутність бачення довгострокової перспективи страхового маркетингу.

3. Стабільне використання маркетингу в страховій діяльності потребує додаткового фінансування. Даний нюанс часто сприймається страховиками як дороге “задоволення", тобто зайва стаття витрат.

4. На маркетингові досягнення в сфері розробки нових страхових продуктів відсутня можливість проведення процедури патентування, що сприяє швидкому копіюванню та використанню найефективніших з них конкурентами.

5. Відсутня державна підтримка та стимулювання в сфері використання маркетингу в страховій діяльності.

Впроваджуючи маркетинговий відділ в страхову компанію, слід пам'ятати, що дана діяльність в сфері страхування характеризується специфічними особливостями, які принципово відрізняють його від звичайного маркетингу:

- передбачається детальне вивчення та аналіз різноманітних типів ризиків, як невід'ємної складової страхових продуктів (отримана інформація сприятиме розробці можливих управлінських рішень для мінімізації їх впливу та якісного задоволення потреб споживачів);

- не слід забувати про період життя страхових продуктів, який зазвичай характеризується довгостроковим характером співпраці страхової компанії та страхувальника, що дає змогу реально оцінити переваги від отримання страхових послуг тільки з роками взаємодії;

- в процесі розробки маркетингових рішень слід враховувати на чому вони концентруються: просуванні страхового продукту для конкретного страхувальника чи для групи його потенційних споживачів.

На думку А.Н. Зубця, маркетинговий відділ страхової компанії концентрує свою увагу на певних сферах діяльності (рис 1). Кожна із зазначених сфер страхового маркетингу виступає життєво необхідною складовою стабільного та прибуткового функціонування страхової компанії.

Аналіз страхового ринку необхідна вимога для 

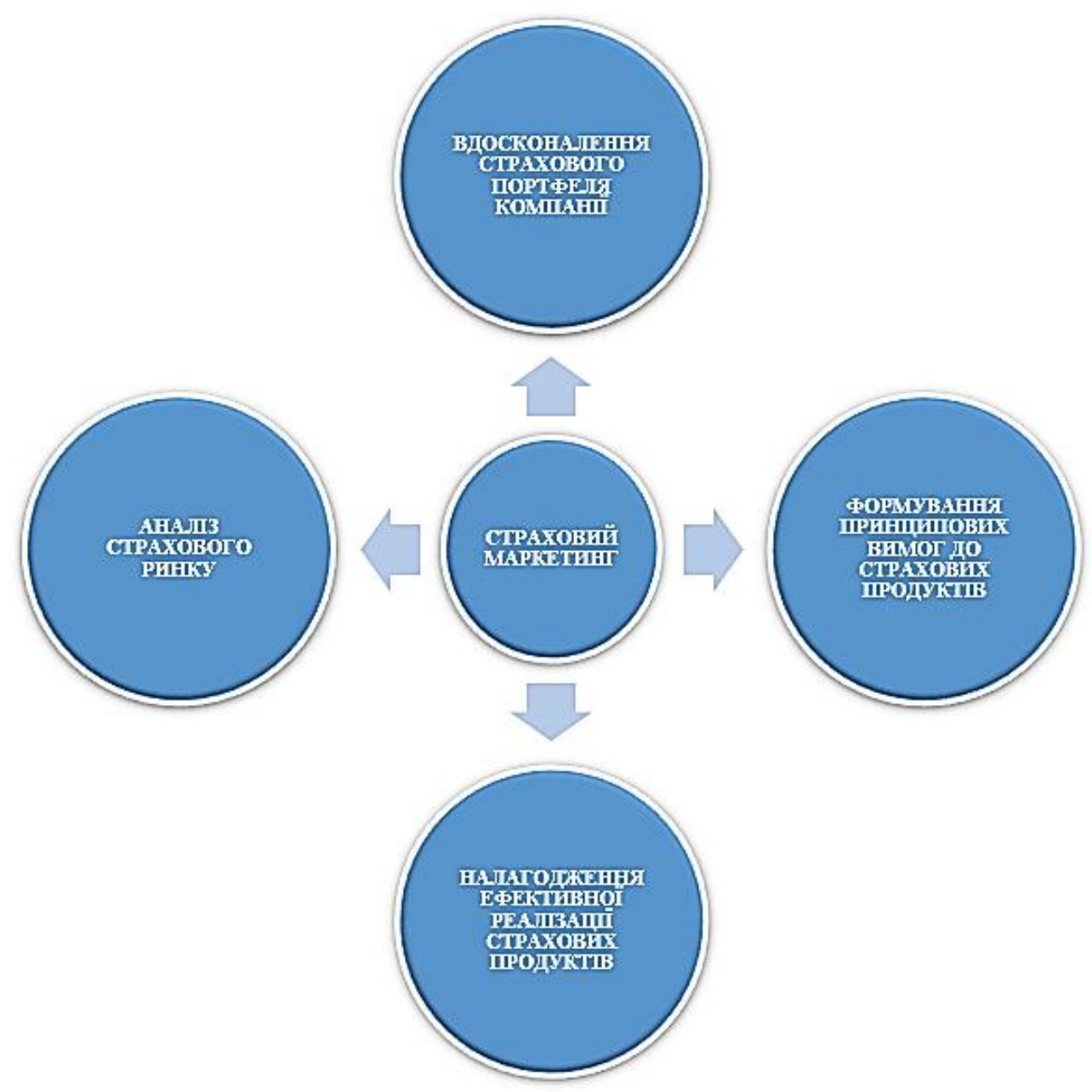

Рис 1. Основні сфери використання маркетингу в страховій діяльності*

*Джерело: складено автором роботи на основі джерела [4, с. 14]

побудови високоефективного страхового маркетингу. Потрібно отримати достовірну інформацію про потенційних клієнтів, ринкову ситуацію загалом та можливості впливати на неї шляхом своєчасної реакції на ринкові зміни. Для виробництва актуальних страхових продуктів мають бути визначені провідні запити страхового ринку. Не менш важлива розробка моделей поведінки на випадок кризових ситуацій на даному ринку. При аналізі страхового ринку слід не забувати про оцінку рівня та форм конкуренції в цілому та характеристиці головних конкурентів власної страхової компанії. Аналіз наявних та потенційних конкурентів сприятиме розробці ефективної маркетингової стратегії. При аналізі конкурентів потрібно виокремити їх ключові фактори успіху й причини невдач, визначити наявну в них частку ринку для вивчення можливостей розширення власного сегменту в страховому ринку, а також оцінити роль маркетингової служби в їх діяльності.

Вдосконалення страхового портфеля компанії починається насамперед із характеристики його слабких та сильних сторін, наприклад аналізу

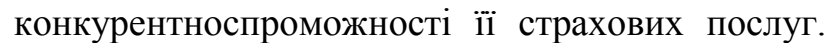
Не менш важливо визначити найрентабельніший 3 наявних страхових продуктів та здійснити оцінку можливостей i необхідності урізноманітнення їх асортименту.

Формування принципових вимог до страхових продуктів зазвичай пов'язане із законодавчими нормами, специфікою конкретного сегменту страхового ринку, а також філософією бізнесу самої компанії. До прикладу: характерною вимогою є бачення, що покращення наявних та розробку принципово нових страхових продуктів потрібно здійснювати 3 врахуванням інтересів страховика та різноманітних універсальних чи унікальних побажань страхувальників; також існує потреба в забезпеченні конкурентноспроможного рівня цін на страхові послуги; не менш важливою вимогою $є$ необхідність в ефективному представленні та якісній реалізації страхового продукту так, щоб негативні відчуття від регулярної сплати страхових внесків майже не відчувалися тощо.

Налагодження ефективної реалізації страхових продуктів певно найважливіша складова 
страхового маркетингу. Потрібно проаналізувати наявні та потенційні канали реалізації страхових послуг, насамперед, вивчити їхню вартість та ефективність. В результаті має бути сформована оптимальна мережа просування страхових продуктів від страховика до страхувальника в зручний для клієнта час та в зручному місці. Не менш важливо забезпечити формування й підтримку стабільного попиту на страхові поліси та їх оптимальної пропозиції, а також проводити, час від часу, вдалі рекламні кампанії та здійснювати ефективну PR-політику. Вплив цих факторів має бути спрямований не лише на клієнтів продукту страховика, а також на партнерів, конкурентів, лідерів думок, політиків та співробітників самої компанії, щоб сформувати сильний бренд та підвищити рівень страхової культури загалом. Полегшити просування

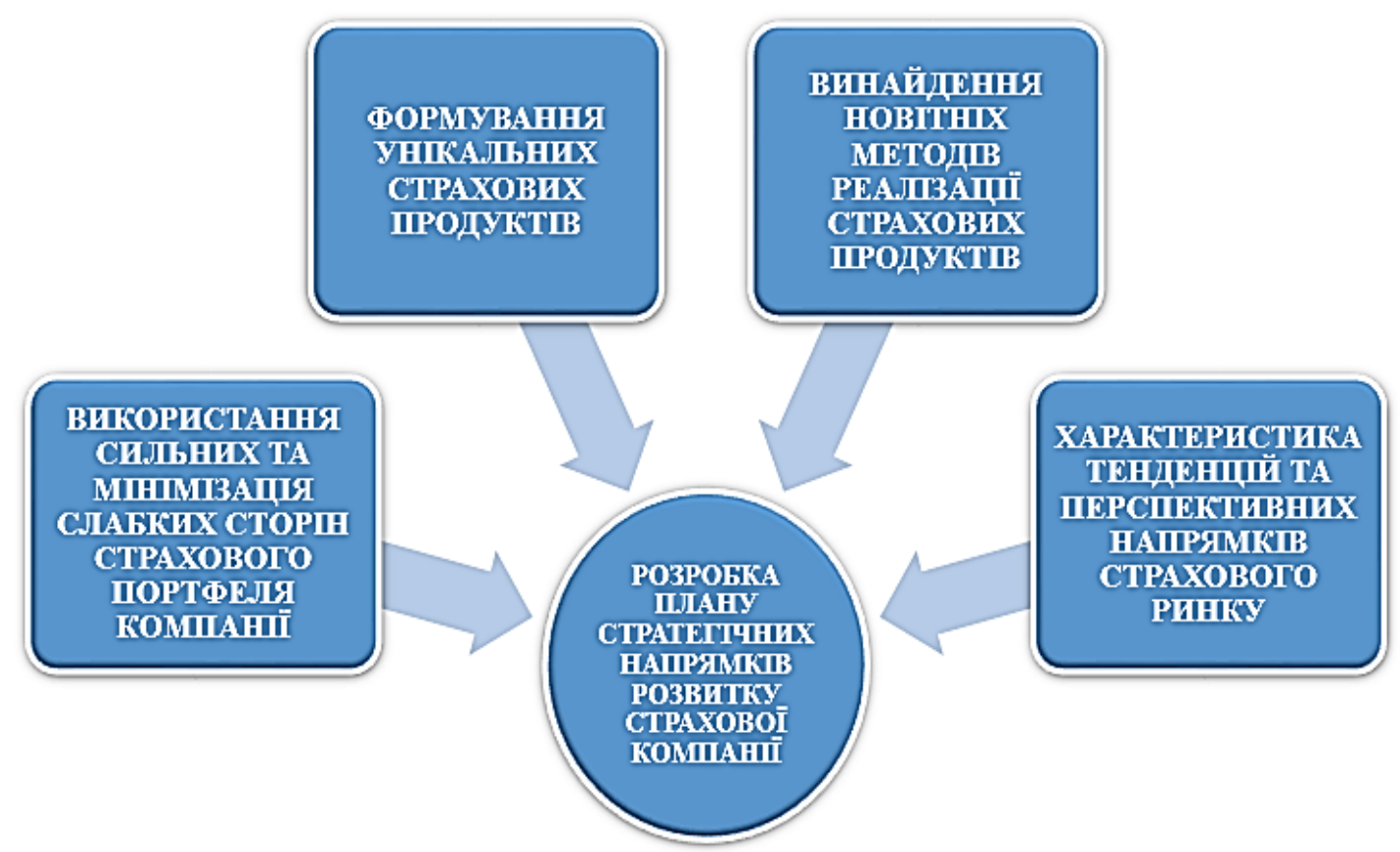

Рис 2. Роль маркетингу в розробці плану стратегічних напрямків розвитку страхової компанії*

* Джерело: власна розробка автора

Отож, інтеграція страхового маркетингу в саму структуру управління компанією сприятиме утриманню іiі в зоні максимально ефективного функціонування. Роль маркетингової діяльності в страхуванні неоціненна, вона сприяє підтримці конкурентних позицій та пошуку нових привабливих сегментів на страховому ринку, розробці моделей стратегічних напрямків розвитку компанії та їх втіленню в життя, реалізації традиційних та принципово нових страхових послуг, залученню важкодоступних груп страхувальників, оптимізації процедури купівлі страхових полісів, а також формуванню Позитивного іміджу бренду компанії в очах страхових послуг може створення та оновлення бази даних постійних клієнтів компанії, а також можливостей сучасних інформаційних технологій, зокрема, мережі Інтернет. Очевидною перевагою продажів через мережу Інтернет $€$ автоматизації самого процесу реалізації страхових послуг, швидкість та зручність оплати переказом, постійний доступ до страхових продуктів 3 будь-якої точки на планеті. Крім прямих продажів, високоефективною $є$ практика використання страхових посередників, які фактично виступають провідними маркетологами в страхуванні та осягають успіху там де великі компанії зазнали краху.

Як підсумок, досягнення зі всіх сфер використання страхового маркетингу сприятимуть розробці плану стратегічних напрямків розвитку страхової компанії (рис 2).

पНАЙДМННЯ

HOBIHHIX

10Ді

МАМЗАЦ

CTPAXOBLX

ШРОДУКТШ

ТЕНДЕНЩЙ ТА

НАIPभMTKIB

CTPAXOBOTO

PRIIK клієнтської бази та суспільства загалом.

Страховий маркетинг може впливати на всі головні сфери функціонування страхової компанії (від розробки якісних управлінських рішень до збільшення прибутків), що неодмінно позначиться на зростанні ринкової вартості компанії та забезпечить їй довгострокову діяльність.

Висновки i перспективи подальших досліджень. Таким чином, ми дійшли висновку, що для залучення все більшої кількості страхових компаній використовувати маркетинг у своій діяльності потрібно визначити причини, які служать бар'єрами стримування. Як показало 
дослідження, можна вказати наступні причини небажання використовувати маркетинг в страхуванні: відсутність навичок та досвіду використання маркетингу на страховому ринку України; небажання страховиків змінювати звичні норми функціонування; сприйняття страхового маркетингу як зайвої статті витрат; відсутність патентування досягнень страхового маркетингу в сфері розробки нових страхових продуктів; відсутність державної підтримки та стимулювання в процесі використання маркетингу в страховій діяльності.

За результатами аналізу, втілення функцій маркетингу в страховій діяльності пов'язане 3 аналізом страхового ринку, вдосконаленням страхового портфеля компанії, формуванням принципових вимог до страхових продуктів та налагодженням їх ефективної реалізації. Як підсумок, досягнення зі всіх сфер використання страхового маркетингу сприятимуть розробці плану стратегічних напрямків розвитку страхової компанії. Зокрема, слід виділити такі досягнення: використання сильних та мінімізація слабких сторін страхового портфеля компанії; формування унікальних страхових продуктів; винайдення новітніх методів реалізації страхових продуктів; характеристика тенденцій та перспективних напрямків страхового ринку. Тому що саме ці кроки $є$ потенційними можливостями для забезпечення світлого й прибуткового майбутнього страхової компанії.

Але, не треба забувати, що обмежених сфер використання маркетингу в страховій діяльності не існує, завжди існують можливості для зростання ролі конкретної діяльності у бізнесі, що не були враховані, а з часом з'являються нові фактори протидії, які потребують свіжого погляду на їх вирішення. Специфічні характеристики максимально ефективного використання маркетингу для конкретної страхової компанії потребують розробки рішень в формуванні відділу страхового маркетингу саме для визначеного випадку. Згідно цього виникає необхідність врахування як вітчизняного, так й іноземного досвіду в сфері використання страхового маркетингу, та виробленні нових шляхів для вирішення зазначеного завдання у відповідних актуальних умовах, що $\epsilon$ перспективою подальших досліджень даної тематики.

\section{ПЕРЕЛІК ВИКОРИСТАНИХ ДЖЕРЕЛ:}

1. Алексунина В.А. Маркетинг в отраслях и сферах деятельности: Учебник под редакцией проф. Алексунина В.А..- М.: Издательско-книготорговый центр "Маркетинг", 2001, - 516с.

2. Говорушко Т. А. Страхові послуги: [навч. посіб.] / Говорушко Т. А. [2-ге видання перероблене і доповнене]. - К. : Центр учбової літератури, 2008. - 344 с.

3. Заруба О. Д. Страхова справа: [підручник] / Заруба О. Д. - К. : Товариство “Знання”, КОО, 1998. - 321 с.

4. Зубец А. Н. Страховой маркетинг - М. : Издательский дом “АНКИЛ”, 1998. - 250 с.

5. Зубец А.Н. Маркетинговые исследования страхового рынка - М.: Центр экономики и маркетинга, 2001. $224 \mathrm{c}$.

6. Уткина Э.А. Справочник по страховому бизнесу/ под редакцией проф. Уткина Э.А.- М.: Ассоциация авторов и издателей «ТАНДЕМ» Издательство ЭКМОС, 1998. - 416с.

\section{REFERENCES}

1. Aleksunina, V. A. (2001). Marketing v otrasliah i sferah deiatelnosti [Marketing in branches and fields of activity]. Moscow: The Center of publishing-bookstore «Marketing» [in Russian].

2. Govorushko, T. A. (2008). Strakhovi poslugi [Insurance services]. Kyiv: The Center of Educational Literature [in Ukrainian].

3. Zaruba, O. D. (1998). Strakhova sprava [Insurance business]. Kyiv: Znannia [in Ukrainian].

4. Zubetc, A. N. (1998). Strakhovoi marketing [Insurance Marketing]. Moscow: The Publishing house «ANKYL» [in Russian].

5. Zubetc, A. N. (2001). Marketingovie issledovaniia strakhovogo rinka [Marketing researches of the insurance market]. Moscow: The Center of Economics and Marketing [in Russian].

6. Utkina, E.A. (1998). Spravochnik po strakhovomu biznesu [Insurance business handbook]. Moscow: Association of authors and publishers «TANDEM» [in Russian].

Одержано 10.09.2018 p. 